University of Nebraska - Lincoln

DigitalCommons@University of Nebraska - Lincoln

USDA National Wildlife Research Center - Staff Publications
U.S. Department of Agriculture: Animal and Plant Health Inspection Service

2012

\title{
Double-Crested Cormorant Distribution on Catfish Aquaculture in the Yazoo River Basin of Mississippi
}

\author{
Brian S. Dorr \\ Loren W. Burger \\ Mississippi State University \\ Scott C. Barras \\ U.S. Department of Agriculture \\ Kristina Casscles Godwin \\ U.S. Department of Agriculture
}

USDA/APHIS/WS National Wildlife Research Center, brian.s.dorr@aphis.usda.gov

Follow this and additional works at: https://digitalcommons.unl.edu/icwdm_usdanwrc

Dorr, Brian S.; Burger, Loren W.; Barras, Scott C.; and Casscles Godwin, Kristina, "Double-Crested Cormorant Distribution on Catfish Aquaculture in the Yazoo River Basin of Mississippi" (2012). USDA National Wildlife Research Center - Staff Publications. 1082.

https://digitalcommons.unl.edu/icwdm_usdanwrc/1082

This Article is brought to you for free and open access by the U.S. Department of Agriculture: Animal and Plant Health Inspection Service at DigitalCommons@University of Nebraska - Lincoln. It has been accepted for inclusion in USDA National Wildlife Research Center - Staff Publications by an authorized administrator of DigitalCommons@University of Nebraska - Lincoln. 


\title{
Double-Crested Cormorant Distribution on Catfish Aquaculture in the Yazoo River Basin of Mississippi
}

\author{
BRIAN S. DORR, ${ }^{1}$ United States Department of Agriculture, Wildlife Services, National Wildlife Research Center, Mississippi Field Station, \\ P.O. Box 6099, Mississippi State University, MS 39762, USA \\ LOREN W. BURGER, Department of Wildlife, Fisheries and Aquaculture, Mississippi State University, Box 9690, Mississippi State University, \\ MS 39762-9690, USA \\ SCOTT C. BARRAS, United States Department of Agriculture, Wildlife Services, P.O. Box 130, Moseley, VA 23120, USA \\ KRISTINA CASSCLES GODWIN, United States Department of Agriculture, Wildlife Services, P.O. Drawer FW, 200 Thompson Hall, \\ Mississippi State University, MS 39762, USA
}

\begin{abstract}
Estimating the catfish aquaculture production losses that can be attributed to double-crested cormorants (Phalacrocorax auritus) has proved problematic because knowledge of the distribution of cormorants on catfish aquaculture is lacking. We evaluated use versus availability of various production pond types and landscape-scale factors affecting the distribution of cormorants on channel catfish (Ictalurus punctatus) aquaculture facilities in Mississippi, USA. Cormorant distribution on aquaculture pond types indicated selection against brood-fish ponds, neutral selection on fingerling ponds, and selection for food-fish ponds ( $n=29$, Chesson's $\alpha=0.19,0.36$, and 0.45 , respectively). Modeled and validated correct classification rate (CCR) of general linear mixed models of cormorant occupancy of clusters of catfish ponds indicated seasonality of use and roost distance from aquaculture ponds was predictive $(\mathrm{CCR}=81 \%$ and $71 \%$, respectively). Modeled and validated ordinal models of levels of use (low, moderate, high) were less predictive (CCR $=67 \%$ and $59 \%$, respectively). However, predictability within use levels for the validation data set was mixed, ranging from 0.19 to 0.86 . Odds ratios indicate both higher risk of occupancy and levels of use over the period February-April relative to October. Management efforts targeted during this time frame will have the greatest impact in reducing depredation losses. The majority of cormorants occurred on food-fish ponds. Consequently estimates of economic loss should be revisited and refined based on distributional information provided in this study. Published 2012. This article is a U.S. Government work and is in the public domain in the USA.
\end{abstract}

KEY WORDS aquaculture, cormorants, distribution, Phalacrocroax auritus, predation, selectivity.

The double-crested cormorant (Phalacrocorax auritus; hereafter, cormorant) is considered the primary depredating bird species on commercially produced channel catfish (Ictalurus punctatus; hereafter, catfish) in Mississippi, USA (Wywialowski 1999, Glahn et al. 2002, Dorr et al. 2008). In the past $30 \mathrm{yr}$, cormorant abundance has increased dramatically in the United States (Hatch and Weseloh 1999) and specifically within the catfish aquaculture-producing regions of Mississippi. Past research on cormorant predation of commercially raised catfish focused on food habits, bioenergetics modeling, night-roost surveys, and extrapolation of these data to estimate potential economic losses (Stickley et al. 1992, Glahn and Brugger 1995, Glahn and Stickley 1995, Glahn et al. 1996). These estimates of economic loss due to cormorants have largely been valued at replacement cost of catfish fingerlings because distributional information

Received: 15 February 2011; Accepted: 16 October 2011;

Published: 4 January 2012

${ }^{1}$ E-mail: brian.s.dorr@aphis.usda.gov on where predation was occurring was unknown. These loss estimates can vary widely dependent on whether predation impacts are valued to gross (i.e., at-harvest) catfish production rather than fingerling replacement costs (Glahn and Dorr 2002, Glahn et al. 2002).

Research has identified and refined the range of production losses that can be attributed to cormorants and how cormorant predation can affect production and net returns per pond (Glahn and Dorr 2002, Glahn et al. 2002). Most of the catfish consumed by cormorants are within the range of sizes commonly stocked and present in both fingerling and foodfish production ponds (Glahn et al. 1995, 2002). Cormorants are, therefore, capable of consuming catfish from the majority of catfish ponds in production. However, the impacts on economic loss of cormorant predation on fingerling as opposed to food-fish ponds differ widely. Glahn et al. (2002) and Glahn and Dorr (2002) estimated that losses at harvest may be as much as 5 times greater than simple replacement cost if losses occur on food-fish ponds compared with fingerling ponds. Further Glahn et al. (1995) found that 
cormorant diet differed significantly depending on where cormorants were night roosting within the Yazoo Basin. Thus, economic impacts to the aquaculture industry cannot be accurately assessed and monitored without estimates of how cormorants are distributed geographically within the aquaculture-producing regions of Mississippi and on aquaculture facilities. In addition, management efforts to alleviate impacts cannot be effectively evaluated without understanding influences of cormorant distribution on aquaculture. The objective of this study was to evaluate factors affecting use and selectivity of various production catfish pond types on aquaculture ponds in Mississippi using aerial surveys in a random stratified single-stage cluster sampling design (Levy and Lemeshow 1999, Dorr et al. 2008).

\section{STUDY AREA}

We sampled at randomly selected clusters of catfish ponds in approximately 258,000 ha of the primary catfish aquaculture-producing area of the $18,000-\mathrm{km}^{2}$ Mississippi alluvial plain area of the Yazoo River Basin of northwestern Mississippi (Yazoo Basin; Fig. 1). The Yazoo River proper began at the confluence of the Tallahatchie and Yalobusha rivers near Greenwood, Mississippi. The Yazoo River then flowed southwest for $315 \mathrm{~km}$ to join with the Mississippi
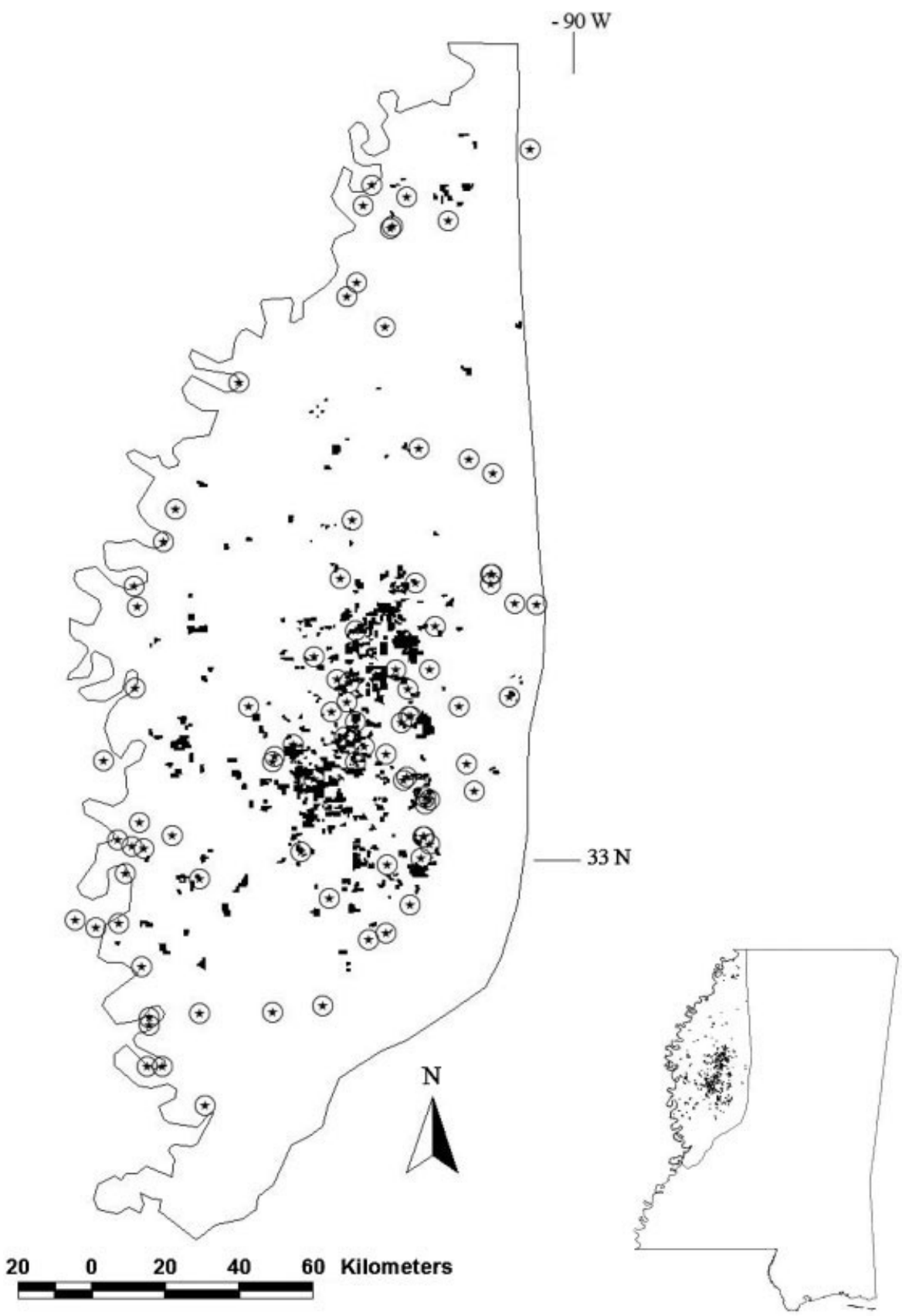

Figure 1. Map of the Yazoo Basin of Mississippi, USA. Black shapes represent known extent of catfish aquaculture ponds and centered circles represent known double-crested cormorant (Phalacrocorax auritus) night-roost locations surveyed during the winters (Oct-Apr) 2000-2001 and $2003-2004$. 
River near Vicksburg, Mississippi. The region was primarily level farmland, with alluvial soils consisting of clay and fine sand (Shields et al. 2008). Clusters were determined by overlaying U.S. Geological Survey land-survey section polygons (1993, 7.5-Min Quadrangle) over geographic information system coverage of ponds in the Yazoo Basin (Landsat L7, Enhanced Thematic Mapper, orthorectified, terrain-corrected, $\pm 15-\mathrm{m}$ resolution) provided by Ducks Unlimited, Inc. (Memphis, TN). A pond was considered within a cluster if $>50 \%$ of the pond was within the section.

Glahn et al. (1995) reported that cormorants that roosted on or near the Mississippi River had a lower percentage of catfish in the diet than cormorants that roosted in the interior of the Yazoo Basin. Glahn et al. (1995) attributed these results to several factors, including a lower density of catfish ponds and greater available natural foraging habitat. Owing to these findings, and to evaluate whether detectable differences in use of clusters existed, we stratified the cluster sampling by river and interior regions of the Yazoo Basin (Fig. 2). All clusters west of longitude $90.85^{\circ} \mathrm{W}$ were considered to be in the river region, while clusters east of this to the Loess Bluffs (Shelford 1963) were considered to be in the interior region (Mott et al. 1998, Tobin et al. 2002, Dorr et al. 2008). Twenty percent of identified clusters (sampling units) from each region were randomly selected from the geographic information system coverage of these ponds in
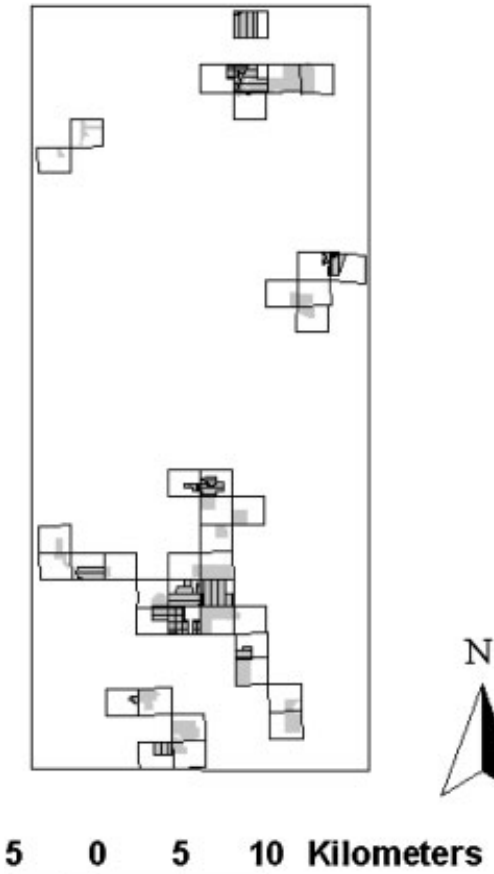
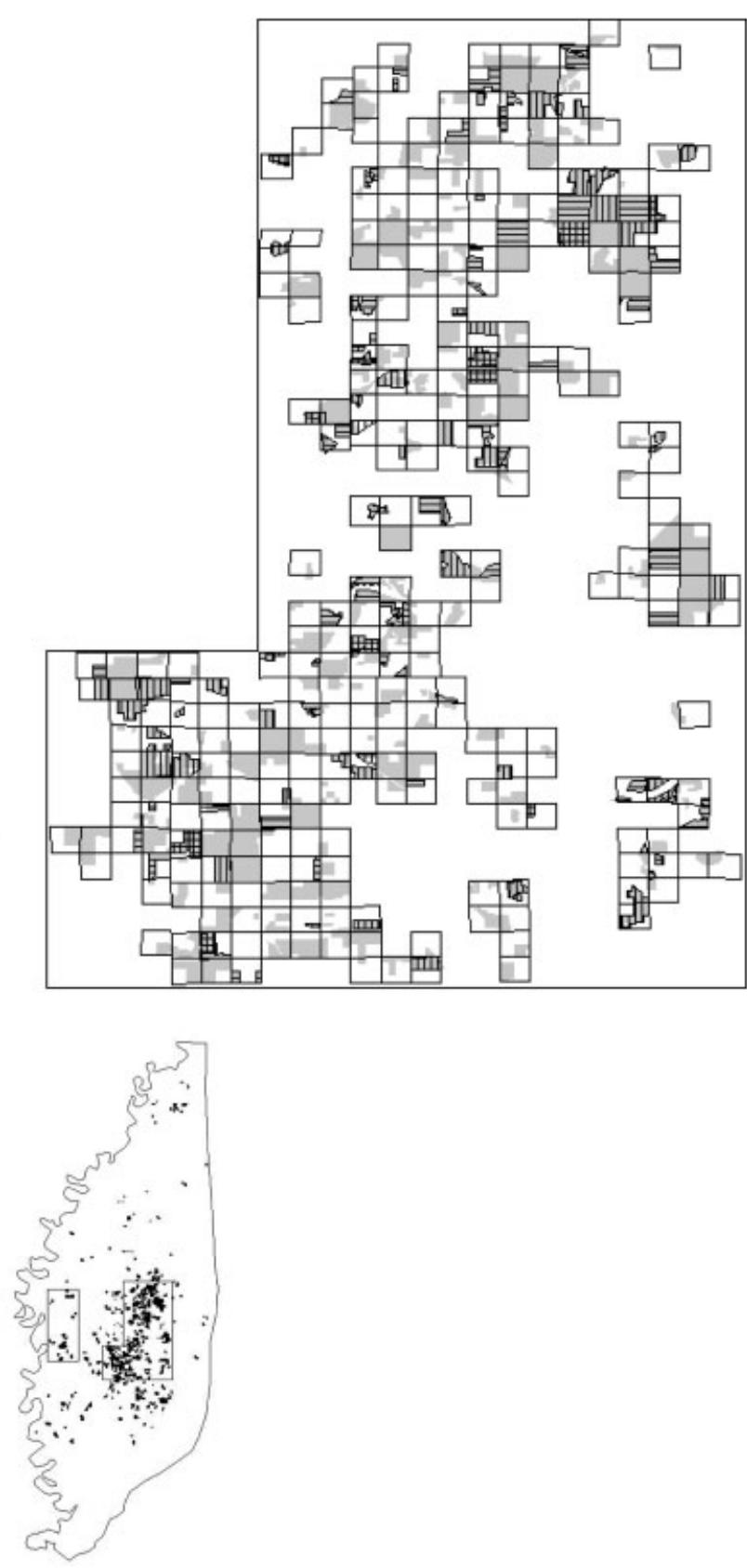

Figure 2. Study area for estimating distribution and abundance of double-crested cormorants (Phalacrocorax auritus) in the primary aquaculture-producing area of the Yazoo Basin of Mississippi, USA. Bounded areas represent river and interior regions; shaded areas represent clusters of catfish aquaculture ponds sampled in winter (Oct-Apr). Vertical bars represent clusters sampled in winter 2000-2001; horizontal bars represent clusters sampled in winter 2003-2004; crosshatched areas represent clusters sampled in both winters. 
the Yazoo Basin. Regions were separated spatially by mean foraging distance as reported by King (1996) to maximize independence of cormorant counts between regions.

\section{METHODS}

\section{Aerial Surveys}

We flew aerial surveys 2 days/month using a Cessna (Wichita, KS) 172 fixed-wing aircraft, except for October 2000 , during which an additional initial survey was flown to insure the sample area could be fully surveyed given constraints on flight duration. We flew surveys from October 2000 to April 2001, and from October 2003 through April 2004. This period encompasses most cormorant winter movements through the Yazoo Basin (Dorr et al. 2008). Each flight took approximately $8 \mathrm{hr}$ to complete. Due to logistical constraints and to minimize double-counting of cormorants within the survey area, we limited flights to $<8 \mathrm{hr}$ to complete counts in a single day. Each survey began at approximately 0800 hours, weather permitting, and was shifted $1 \mathrm{hr}$ for daylight savings time. We alternated the starting point at random between interior and river regions to reduce potential bias resulting from diurnal patterns of cormorant feeding behavior (Dorr et al. 2008). For each survey, the pilot circled clusters at an altitude of 100-150 m, and all cormorants observed on each pond within each cluster were counted by a single observer. We adjusted counts of cormorants on ponds for a visibility correction factor specific to cormorants on catfish ponds (from Dorr et al. 2008). There are other factors that may affect detection in aerial surveys (e.g., distance, behavior). We did not adjust for detection probabilities for these factors because cormorants typically respond to the aircraft with alert behavior (Dorr et al. 2008) and catfish ponds are a relatively small (on average, $205 \mathrm{~m}^{2}$ ) and homogenous habitat with few, if any, visual obstructions. We ground-truthed all ponds within selected clusters by production type; brood-fish, food-fish, or fingerling ponds. We categorized fingerling ponds as those ponds with fish of 3-20 cm, and 1-27 kg/1,000 fingerlings. Food-fish ponds were made up of fish of marketable size, typically $\geq 25 \mathrm{~cm}$ and up to $1.4 \mathrm{~kg} / \mathrm{fish}$, and brood-fish ponds were ponds containing sexually mature catfish used for reproduction, which were typically as large as or larger than food-fish (U.S. Department of Agriculture [USDA] 2003a, $b$, parts I and II).

Our aerial pond surveys were coordinated with USDA Wildlife Services-Mississippi (WS-MS) aerial surveys of cormorant night roosts; surveys were flown within $24 \mathrm{hr}$ of each other weather permitting. The WS-MS night-roost surveys followed the procedures of Glahn et al. (1996) and were conducted within the first $3 \mathrm{hr}$ after sunrise and before sunset. The pilot flew over all known night-roost locations $(N=80)$ in the delta region, circling active roosts at an altitude of 150-200 m, while an observer counted all cormorants in the roost. Night-roost counts provided information on the distribution of cormorants relative to active night roosts and a total count of cormorants for the entire Yazoo Basin. Pond counts provided descriptive statistics of percent- age use versus availability for each pond type within and between years.

\section{Statistical Analyses}

We used the Manly-Chesson selectivity index as a measure of selection for pond types (Chesson 1978, 1983; Eisenhower and Parrish 2009). Use versus availability was based on pond area rather than number because food-fish ponds are, on average, larger than fingerling ponds (Steeby and Avery 2002). We arcsine-square-root transformed proportion (i.e., percentage) data prior to evaluation of selectivity (Steel and Torrie 1980). The selectivity index alpha $(\alpha)=\left(r_{i} / n_{i}\right) /\left[\Sigma\left(r_{i} / n_{i}\right)\right]$, equaled 1 summed across pond types (Eisenhower and Parrish 2009), where $r_{i}$ was the proportion of ponds of type $i$ on which cormorants were observed, and $n_{i}$, was the proportion of ponds of type $i$ surveyed. We calculated 95\% confidence interval estimates around $\alpha$ for all surveys combined. We considered that there was no selection for a pond type if the $95 \%$ confidence interval for $\alpha$ overlapped $1 / \mathrm{m}$, where $\mathrm{m}$ equals the area of pond types available (i.e., $1 / \mathrm{m}=0.33$; Eisenhower and Parrish 2009, Carter et al. 2010).

We developed an a priori global model to explain presence or absence and ordinal level of use by cormorants of aquaculture ponds. Three sources of variation were incorporated into the models: month, region, and a landscape-scale metric (N-AVAIL) estimating numbers of cormorants available to a given cluster on a given survey date. The metric N-AVAIL was developed because multiple active roost sites could potentially contribute birds to any given cluster on any given survey date. We determined the metric by pairing aerial surveys of numbers of cormorants observed on catfish ponds with WS-MS aerial night-roost counts for the Yazoo Basin for a given time period. The metric N-AVAIL incorporated distance from night roost to a given cluster, and number of cormorants counted in a given night roost, adjusted for the observed foraging distances of very high frequency-marked birds as reported by Tobin et al. (2002:48 [Table 2]). We made this adjustment by multiplying the observed cumulative percentage frequency distribution of cormorant movements from night roosts to next-day foraging locations for a given $10-\mathrm{km}$ distance category (Fig. 3) by the numbers of cormorants counted for a given roost on a given aerial survey date. The sum of the number of cormorants adjusted for observed distance and number counted provided a unique cumulative total of cormorants available to each cluster for each survey period.

We evaluated effects of metrics on presence or absence and level of use of cormorants on clusters using SAS (version 9.1) PROC GLMMIX (SAS Institute 2005). We analyzed the binary data by fitting a general linear mixed model with logit link and binomial error distribution. Ordinal response categories were developed to associate a level of use (i.e., predation risk) with predictive factors. We analyzed ordinal response models estimating number of cormorants on clusters by fitting a general linear mixed model with $\log$ link and multinomial error distribution (SAS Institute 2005). In binary and ordinal models, we modeled month, region, 


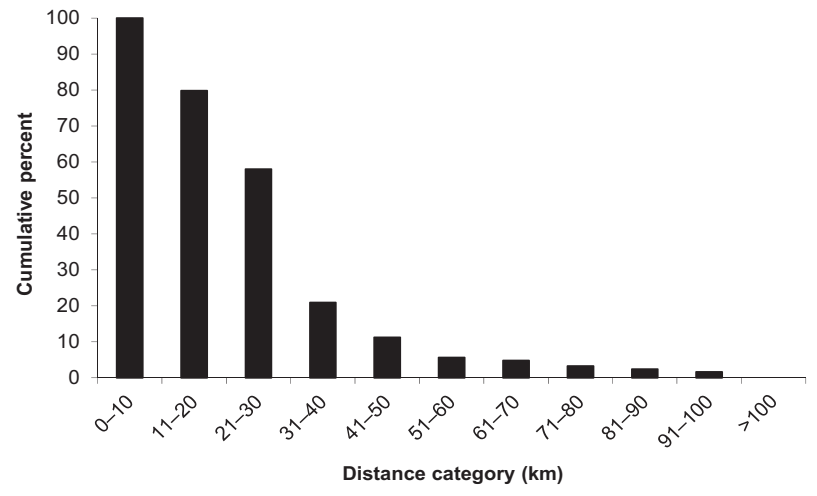

Figure 3. Cumulative percentage frequency distribution of double-crested cormorant (Phalacrocorax auritus) movements from night roosts to next-day foraging locations in the Yazoo Basin of Mississippi, USA, for a given 10-km distance category, 15 January-10 March 1997 (data source: Tobin et al. 2002:48).

and N-AVAIL as fixed effects and cluster and year were modeled as random effects. Because SAS version 9.1 PROC GLMMIXED uses pseudo-likelihood estimation methods for models with random effects, information theoretic methods of model selection are not comparable among models (SAS Institute 2005). Due to this constraint, we evaluated independent variables based on individual Type III $F$ tests. Independent variables significantly $(P<0.10)$ related to the response variable were retained in the reduced model (Pope and Webster 1972). We built global and reduced models on a randomly selected subset of $75 \%$ of the total number of observations. All resulting models were validated on a randomly selected subset of $25 \%$ of the observed data.

We evaluated predictive capability of binary models by developing a classification table of sensitivity (no. of cormorants present that were correctly classified as present) and specificity (no. of cormorants absent that were correctly classified as absent) of modeled versus observed presence or absence on the validation data set. The a priori cutpoint for determining classification category was 0.50 (Affifi and Clark 1990). The combined totals for specificity and sensitivity are a measure of the proportion correctly classified or correct classification rate (CCR; Hosmer and Lemeshow 2000).

Ordinal responses were associated with observed levels of predation significant with respect to economic loss estimates. We developed three ordinal response categories of low $(\leq 1 /$ cormorant/cluster), moderate ( $>1$ to $\leq 22 /$ cormorants/cluster), and high levels ( $>22 /$ cormorants/cluster) of cormorant use (modeled levels 1, 2, and 3) based on economic considerations of cormorant use of catfish aquaculture ponds (Glahn et al. 2002). Glahn et al. (2002) found that production and associated losses in profits occur when predation reaches approximately 500 cormorant-days of predation $/ \mathrm{ha} /$ yr. For an average 4.5-ha food-fish pond (USDA 2003b, part II) this equates to an average of approximately 11 cormorants/pond during the wintering period October-April. The maximum value for moderate use was 22 cormorants because, on average, 2 ponds/cluster were utilized by cormorants. We determined ordinal response categories by calculating the marginal probabilities (Norusis 2005) of occurrence of each response level, with the largest probability determining the response value (e.g., if $P$ level $1>P$ level 2 and $P$ level $1>P$ level 3, then level $=$ low). The descending option in the GLIMMIX procedure was used to model the probabilities of levels of the response variable having higher ordered values (i.e., the least value is the reference). We evaluated model fit and predictive capability of ordinal response models of cormorant use based on within-level and overall CCR against the validation data set.

We interpreted parameters of interest for selected models by description of their associated odds ratios (OR; Keating and Cherry 2004). The OR is a measure of association that estimates how much more or less likely is a given outcome (Affifi and Clark 1990, Hosmer and Lemeshow 2000). The relationship for a logistic model with a dichotomous independent variable (i.e., interior or river regions) is $\mathrm{OR}=\mathrm{e}^{b_{i}}$, where $\mathrm{e}^{b_{i}}$ is the inverse natural $\log$ of parameter estimate $b_{i}$. A value for change in $x$ may be a value other than 1 (i.e., $\mathrm{N}$ AVAIL). In this case, the log OR for a change in $c$ units in $x$ is obtained from the logit difference $g(x+c)-g(x)=c b$ (Hosmer and Lemeshow 2000:63). For the variable NAVAIL, we based the value of $c$ on the average number of cormorants available over both years by the associated slope parameter estimate. All tests of significance were conducted at $P=0.05$. Data are presented as means \pm standard error.

\section{RESULTS}

We flew 29 aerial surveys over the 2 -yr study period. We flew 15 from 10 October 2000 to 17 April 2001 and 14 from 15 October 2003 to 20 April 2004. In 2000-2001 (yr 1), we sampled 66 clusters $(58$ from the interior and 8 from the river region). One cluster in the interior region was dropped because ponds were out of production. In 2003-2004 (yr 2), we sampled 65 clusters (58 from the interior and 7 from the river region). One cluster each in the interior and river regions were dropped from aerial surveys because ponds were out of production. Twenty total aerial night-roost surveys were flown by WS-MS, 10 in each year.

The percentage of pond types available by area averaged over each survey period for both years was: brood-fish ponds, 2.0\%; fingerling ponds, $17.2 \%$; and food-fish ponds, $80.8 \%$. The percentage of pond types used by cormorants averaged over each survey period for both years was: brood-fish ponds, 1.1\%; fingerling ponds, $14.5 \%$; and food-fish ponds, $84.4 \%$. Chesson's $\alpha$ indicated selection against brood-fish ponds, neutral selection for fingerling ponds, and selection for foodfish ponds (Fig. 4). The 95\% confidence intervals for Chesson's $\alpha$ overlapped between food-fish and fingerling ponds.

The metric N-AVAIL and month explained statistically significant portions of occurrence of cormorants on catfish aquaculture ponds $\left(n=983, F_{1,845}=7.2, P>F=0.008\right.$ and $F_{6,845}=17.2, P>F<0.001$, respectively). Region was not significant in explaining variation in occurrence of cormorants on clusters. Within-model sensitivity for both the global and reduced models was $83 \%$, specificity was $79 \%$, 


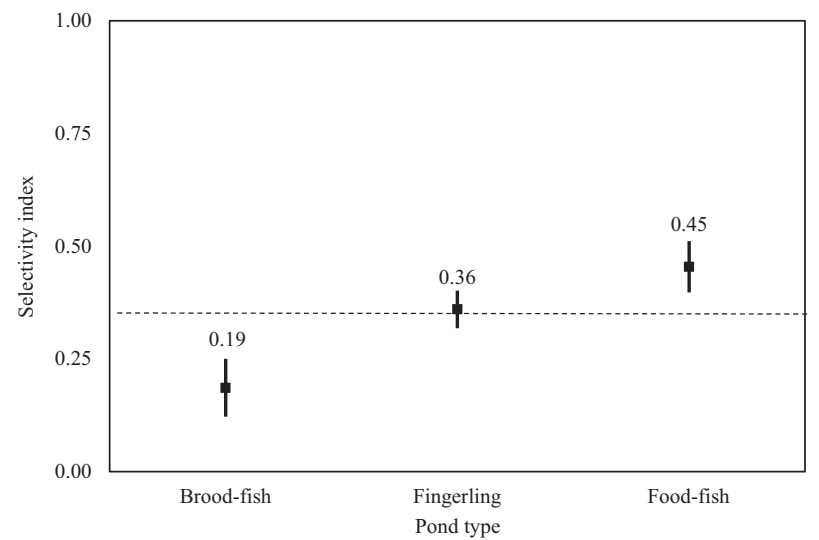

Figure 4. Mean Chesson's $\alpha$ for area of brood-fish, fingerling, and food-fish ponds aerially surveyed in the Yazoo Basin of Mississippi, USA, winters 2000-2001 and 2003-2004. Vertical bars indicate 95\% confidence interval values. Dashed line at $\alpha=0.33$ indicates no selectivity by double-crested cormorants (Phalacrocorax auritus), values $>0.33$ indicate positive selectivity, values $<0.33$ indicate negative selectivity $(n=29)$.

and the CCR was $81 \%$. When applied to the randomly selected validation data set, both global and reduced model sensitivity was $72 \%$, specificity was $69 \%$, and the CCR was $71 \%$. Odds ratios indicated that a given cluster is 7.2 times more likely to have cormorants in March than October and 1.4 times more likely at the mean N-AVAIL of 8,082 compared with the minimum N-AVAIL of 100 (Table 1).

The metric N-AVAIL and month explained statistically significant portions of occurrence of cormorants on catfish aquaculture ponds for the ordinal model $(n=983$, $F_{1,844}=7.8, \quad P>F=0.006$ and $F_{6,844}=18.1, \quad P>$ $F<0.001$, respectively). Within-model overall CCR for both the global and reduced models was 67\% (Table 2). When applied to the randomly selected validation data set, overall correct classification for both the global and reduced models was 59\%. Within-model sensitivity (positive classification rate) was $91 \%$ for low $(n=517), 26 \%$ for moderate $(n=247)$, and $54 \%$ for high $(n=219)$ use levels for both global and reduced models. Validation model sensitivity was $86 \%$ for low $(n=159), 19 \%$ for moderate $(n=95)$, and $53 \%$ for high $(n=73)$ use levels for both

Table 1. Reduced model parameter estimates, standard errors (SE), probability of a greater $t$-value $(P>t)$ and odds ratios $(\mathrm{OR})$ predictive of presence or absence ( 1 or 0 ) of double-crested cormorants on aquaculture ponds in the Yazoo Basin of Mississippi, USA, winters (Oct-Apr) 2000-2001 and 20032004.

\begin{tabular}{lccccc}
\hline Parameter & df & Estimate & SE & $\boldsymbol{P}>\boldsymbol{t}$ & OR \\
\hline N-AVAIL $^{\mathrm{a}}$ & 845 & $4.0^{-05}$ & $1.5^{-05}$ & 0.008 & 1.40 \\
Oct $^{\mathrm{b}}$ & & 0 & & & \\
Nov & 845 & -0.47 & 0.34 & 0.17 & 0.63 \\
Dec & 845 & -0.54 & 0.34 & 0.11 & 0.58 \\
Jan & 845 & -0.27 & 0.28 & 0.34 & 0.77 \\
Feb & 845 & 1.19 & 0.30 & $\leq 0.001$ & 3.28 \\
Mar & 845 & 1.98 & 0.33 & $\leq 0.001$ & 7.22 \\
Apr & 845 & 1.10 & 0.30 & $\leq 0.001$ & 3.00 \\
\hline
\end{tabular}

${ }^{a}$ Reference N-AVAIL is the difference between the min. and mean no. of double-crested cormorants counted (min. $=100$, mean $=8,082$, $n=1,310, \mathrm{SE}=241$ ).

${ }^{\mathrm{b}}$ Oct is the reference month set to $=0$.
Table 2. Reduced model parameter estimates, standard errors (SE), probability of a greater $t$-value $(P>t)$ and odds ratios $(\mathrm{OR})$ predictive of levels of use (low $=1$, moderate $=2$, high $=3$ ) by double-crested cormorants on aquaculture ponds in the Yazoo Basin of Mississippi, USA, winters (OctApr) 2000-2001 and 2003-2004. The odds ratios represent the relative probability of having higher ordered values (moderate or high use) relative to low use.

\begin{tabular}{lccccc}
\hline Parameter & df & Estimate & SE & $\boldsymbol{P}>\boldsymbol{t}$ & OR \\
\hline N-AVAIL $^{\mathrm{a}}$ & 844 & $3.4^{-05}$ & $1.2^{-05}$ & 0.006 & 1.30 \\
Oct $^{\mathrm{b}}$ & & 0 & & & \\
Nov & 844 & -0.28 & 0.34 & 0.41 & 0.76 \\
Dec & 844 & -0.53 & 0.34 & 0.12 & 0.59 \\
Jan & 844 & -0.15 & 0.28 & 0.59 & 0.86 \\
Feb & 844 & 1.32 & 0.28 & $\leq 0.001$ & 3.73 \\
Mar & 844 & 1.75 & 0.29 & $\leq 0.001$ & 5.75 \\
Apr & 844 & 1.12 & 0.28 & $\leq 0.001$ & 3.08 \\
\hline
\end{tabular}

${ }^{a}$ Reference N-AVAIL is the difference between the min. and mean no. of double-crested cormorants counted $(\mathrm{min} .=100$, mean $=8,082$, $n=1,310, \mathrm{SE}=241$ ).

${ }^{\mathrm{b}}$ Oct is the reference month set to $=0$.

global and reduced models. Odds ratios indicated that parameter N-AVAIL is positively related to greater use levels. The months February-April relative to October are positively related to moderate and high aquaculture pond use levels compared with low use levels. Clusters are 5.8 times more likely to have high use by cormorants in March than in October and 1.3 times more likely to have high use at the mean N-AVAIL of 8,082 compared with the minimum NAVAIL of 100 (Table 2).

\section{DISCUSSION}

This study demonstrated seasonality of use of catfish aquaculture ponds and that cormorants were selecting against brood-fish ponds, neutral to fingerling ponds, and selecting for food-fish ponds relative to availability of pond types sampled. Food-fish ponds composed most (81\%) of the ponds surveyed by area and most (84\%) of the cormorants were found on food-fish ponds. Combined, $98 \%$ of cormorants were found on food-fish and fingerling ponds. Although selectivity was shown for food-fish ponds and against broodfish ponds, selection was weak, averaging about $3.6 \%$ for food fish ponds and $0.9 \%$ against brood-fish ponds. Regardless, these data indicate that cormorant distributions on various catfish aquaculture pond types are at least proportional to availability of catfish pond types. This distribution of cormorants on catfish pond types differs from earlier research, which suggested cormorants may prefer fingerling ponds due to their higher stocking densities of catfish and, presumably, more readily consumable size classes (Glahn et al. 1995). However, previous research focused on cormorant foraging on individual ponds and did not assess use versus availability at regional scales.

Our finding on cormorant distribution on catfish aquaculture facilities has important implications with respect to economic loss estimates of cormorant predation on catfish aquaculture. Glahn et al. (2002) suggested that predation of fingerlings from food-fish ponds and consequent economic loss at harvest would correspond to a 5-fold increase over simple replacement cost of fingerling catfish. However, 
previous studies have assumed simple replacement-cost estimates of loss to catfish aquaculture due to cormorant predation (Glahn and Brugger 1995) or have relied on producer surveys to estimate loss (Wywialowski 1999), primarily due to a lack of information on cormorant distribution on aquaculture facilities.

Most food-size catfish are produced in multibatch production systems where multiple age and length classes of catfish are present in a food-fish pond (Tucker et al. 2004). Although this system has production benefits to producers and processors, it has created a wider distribution of consumable-size fish available to cormorants (Glahn et al. 2002). This multibatch production system may facilitate the distribution of cormorants on food-fish catfish aquaculture pond types. Further, it may be energetically favorable for cormorants to consume fewer larger catfish from food-fish ponds than many smaller catfish from fingerling ponds. Given the multibatch production method and the increased losses associated with predation on food-fish ponds (Glahn et al. 2002), alternative culture practices such as "modular production" (Hanson et al. 2007) may be a viable option, particularly in areas of high cormorant use.

Modeling of occupancy of pond clusters by cormorants was predictive within the sample frame. Within-model and validation data indicate seasonality of use and a metric incorporating distance to active night roosts, number of cormorants in an active night roost, and observed foraging distances of cormorants, were predictive of their presence or absence on aquaculture ponds. Odds ratios indicate that cormorants are $7.2,3.7$, and 3.1 times more likely to occur on aquaculture ponds in March, February, and April, respectively relative to October. Interestingly, in October-January, parameter estimates and associated OR did not differ significantly, but were significantly less than in February-April (Table 1). This finding is consistent with previous studies indicating that numbers of cormorants counted from night roosts peaks from January to March (Glahn and Stickley 1995, Glahn et al. 2000). However, the presumed increased use of aquaculture ponds described in previous studies was not derived from actual observation on ponds but was assumed from night-roost counts or anecdotal reports of predation. Glahn et al. (1999) reported that cormorants migrating through aquaculture-producing regions had higher omental fat reserves than cormorants that migrated outside of aquaculture-producing regions. Glahn et al. (1999) hypothesized that cormorant use of aquaculture ponds during the spring may improve condition of birds during spring migration and possibly result in improved condition on their arrival on the breeding grounds. This study documents the seasonality of cormorant use of catfish aquaculture ponds in the Yazoo Basin of Mississippi and an increase in use of aquaculture ponds during spring migration consistent with Glahn et al.'s (1999) hypothesis.

The river and interior regions were not a significant predictor of cormorant use. Current management strategies are focused on moving cormorants from night roosts in highdensity aquaculture regions in the interior Yazoo Basin to lesser density aquaculture regions and regions with greater natural foraging habitat nearer the Mississippi River (Mott et al. 1998, Dorr et al. 2008). The fact that the likelihood of cormorant occupancy of aquaculture ponds between regions is not different suggests that aquaculture producers near the river face similar (but not greater) predation risk as those in the interior. This study was conducted concurrent with harassment programs, so it is not possible to determine whether or how much this predation risk would change if the harassment program were not in place. Furthermore the acreage devoted to catfish aquaculture has steadily declined since 2004. This change in the industry may affect how cormorants are distributed within the region or the intensity of pond use and, consequently, methods used to mitigate losses and their effectiveness.

Although pond counts and night-roost counts were correlated ( $r \geq 0.58$ ), models of the level of risk (i.e., low, moderate, and high) were only marginally predictive. Low and high levels of use were classified reasonably accurately, but sensitivity for moderate levels of use was poor. However, the ordinal model overall was reasonably predictive both for the model and validation data set. Thus, although the risk of occurrence can be modeled, the level of that risk is more difficult to determine, at least for the variables evaluated. Given this caveat, greater levels of use (moderate and high) were associated positively with N-AVAIL, and for the months of February-April compared to October. For all models OR were greater for seasonal patterns relative to numbers of cormorants available to a given cluster. We think it is unlikely that production practice influences this seasonality because the multiple-batch production process makes consumable-size catfish available throughout the year. We suggest that physiological demand during prebreeding spring migration, socially facilitated responses (e.g., presence of conspecifics) and pond- or farm-level characteristics (e.g., presence of disease in catfish) are influencing pond use at a seasonal level.

Werner and Dorr (2006) suggest that night-roost dynamics and pond-specific impacts of cormorants on catfish production are of primary research importance in estimating economic losses to aquaculture. Research and more detailed description of factors affecting use of aquaculture ponds by cormorants at the pond or farm level could provide insights that could be scaled to larger landscape levels and provide greater predictive capability of regional models regarding level of use and potential impacts to aquaculture.

\section{MANAGEMENT IMPLICATIONS}

The distribution and abundance of cormorants on aquaculture facilities in the Yazoo Basin have not been studied at scales larger than a few farms. This study shows that cormorants are distributed on catfish aquaculture ponds at least in proportion to availability of pond types and that occupancy and levels of use are greatest during February-April. Management efforts targeted during this time frame at pond and farm level and regionally will have the greatest impact in reducing predation losses. Lastly, we suggest that economic loss estimates be revisited and refined based on the 
information on cormorant distribution on aquaculture ponds provided in this study.

\section{ACKNOWLEDGMENTS}

U.S. Department of Agriculture/Wildlife Services/National Wildlife Research Center provided funding to conduct this research under Quality Assurance protocol QA-829. We thank staff with U.S. Department of Agriculture, Wildlife Services Mississippi for conducting cormorant night roost surveys, P. Gerard, K. Reinecke, and R. Kaminski for help with statistics and study design, J. Holden, Jr. of Ducks Unlimited, Inc., for catfish pond coverages and A. "Butch" Nygren for his professional aerial survey service.

\section{LITERATURE CITED}

Affifi, A. A., and V. Clark. 1990. Computer aided multivariate analysis. Second edition. Van Nostrand Reinhold, New York, New York, USA.

Carter, M. W., D. E. Shoup, J. M. Dettmers, and D. H. Wahl. 2010. Effects of turbidity and cover on prey selectivity of adult smallmouth bass. Transactions of the American Fisheries Society 139:353-361.

Chesson, J. 1978. Measuring preference in selective predation. Ecology 59:211-215.

Chesson, J. 1983. The estimation and analysis of preference and its relationship to foraging models. Ecology 64:1297-1304.

Dorr, B. S., L. W. Burger, and S. C. Barras. 2008. Evaluation of aerial cluster sampling of double-crested cormorants on aquaculture in Mississippi. Journal of Wildlife Management 72:1634-1640.

Eisenhower, M. D., and D. L. Parrish. 2009. Double-crested cormorants and fish interactions in a shallow basin of Lake Champlain. Waterbirds 32:388-399.

Glahn, J. F., and K. E. Brugger. 1995. The impact of double-crested cormorants on the Mississippi Delta catfish industry: a bioenergetics model. Colonial Waterbirds 18:168-175.

Glahn, J. F., P. J. Dixon, G. A. Littauer, and R. B. McCoy. 1995. Food habits of double-crested cormorants wintering in the Delta region of Mississippi. Colonial Waterbirds 18 Special Publication 1:158-167.

Glahn, J. F., and B. S. Dorr. 2002. Captive double-crested cormorant Phalacrocorax auritus predation on channel catfish Ictalurus punctatus fingerlings and its influence on single-batch cropping production. Journal of the World Aquaculture Society 33:85-93.

Glahn, J. F., A. May, K. Bruce, and D. S. Reinhold. 1996. Censusing double-crested cormorants (Phalacrocorax auritus) at their winter roosts in the Delta region of Mississippi. Colonial Waterbirds 19:73-81.

Glahn, J. F., D. S. Reinhold, and C. A. Sloan. 2000. Recent population trends of double-crested cormorants wintering in the Delta region of Mississippi: responses to roost dispersal and removal under a recent depredation order. Waterbirds 23:137-142.

Glahn, J. F., and A. R. Stickley, Jr. 1995. Wintering double-crested cormorants in the Delta region of Mississippi: population levels and their impact on the catfish industry. Colonial Waterbirds 18 Special Publication 1:137-142.

Glahn, J. F., M. E. Tobin, and J. B. Harrel. 1999. Possible effects of catfish exploitation on overwinter body condition of double-crested cormorants. Pages 147-154 in M. E. Tobin, technical coordinator. Symposium on double-crested cormorants: population status and management issues in the Midwest. U.S. Department of Agriculture-Animal and Plant Health Inspection Service, Technical Bulletin 1879, Washington, D.C., USA.

Glahn, J. F., S. J. Werner, T. Hanson, and C. R. Engle. 2002. Cormorant depredation losses and their prevention at catfish farms: economic considerations. Pages 138-146 in L. Clark, editor. Human conflicts with wildlife: economic considerations. Proceedings of the Third National Wildlife Research Center Special Symposium. National Wildlife Research Center, Fort Collins, Colorado, USA.

Hanson, T. R., J. D. Anderson, G. Ibendahl, J. Steeby, and J. Avery. 2007. Partial budgeting as a decision-making tool for catfish producers with an example for Delta Mississippi catfish producers. Extension Service of Mississippi State University, Publication 2437. <http://msucares.com/ pubs/publications/p2437.pdf>. Accessed 20 Jan 2011.
Hatch, J. J., and D. V. Weseloh. 1999. Double-crested cormorant (Phalarocorax auritus). Account 441 in A. Poole and F. Gill, editors. The birds of North America. The Academy of Natural Sciences, Philadelphia, Pennsylvania, and The American Ornithologists' Union, Washington, D.C., USA.

Hosmer, D. W., and S. Lemeshow. 2000. Applied logistic regression. John Wiley and Sons, New York, New York, USA.

Keating, K. A., and S. Cherry. 2004. Use and interpretation of logistic regression in habitat selection studies. Journal of Wildlife Management 68:774-789.

King, D. T. 1996. Movements of double-crested cormorants among winter roosts in the Delta region of Mississippi. Journal of Field Ornithology 67:205-211.

Levy, P. S., and S. Lemeshow. 1999. Sampling of populations methods and applications. John Wiley and Sons, New York, New York, USA.

Mott, D., J. F. Glahn, P. L. Smith, D. S. Reinhold, K. J. Bruce, and C. A. Sloan. 1998. An evaluation of winter roost harassment for dispersing double-crested cormorants away from catfish production areas in Mississippi. Wildlife Society Bulletin 26:584-591.

Norusis, M. J. 2005. SPSS 13.0 advanced statistical procedures companion. Prentice Hall, Upper Saddle River, New Jersey, USA.

Pope, P. T., and J. T. Webster. 1972. The use of an $F$-statistic in stepwise regression procedures. Technometrics 14:327-340.

SAS Institute. 2005. The GLIMMIX procedure. SAS Institute, Cary, North Carolina, USA.

Shelford, V. E. 1963. The ecology of North America. University of Illinois Press, Urbana, USA.

Shields, F. D., Jr., C. M. Cooper, S. Testa, III, and M. E. Ursic. 2008. Nutrient transport in the Yazoo River Basin, Mississippi. U.S. Department of Agriculture, Agricultural Research Service, Water Quality, Ecology Research Unit, National Sedimentation Laboratory Research Report 60, Oxford, Mississippi, USA: <http://afrsweb.usda. gov/SP2UserFiles/person/5120/NSLReport60.pdf $>$. Accessed 9 Sep 2011.

Steeby, J., and J. Avery. 2002. Construction of levee ponds for commercial catfish production. Southern Regional Aquaculture Center, Publication 101. Mississippi State University, Stoneville, USA: <https://srac.tamu.edu/index.cfm/event/getFactSheet/whichfactsheet/2/>. Accessed 14 Jan 2011.

Steel, R. G. D., and J. H. Torrie. 1980. Principles and procedures of statistics: a biometrical approach. McGraw-Hill, New York, New York, USA.

Stickley, A. R., Jr., G. L. Warrick, and J. F. Glahn. 1992. Impact of doublecrested cormorant depredations on channel catfish farms. Journal of the World Aquaculture Society 23:192-198.

Tobin, M. E., D. T. King, B. S. Dorr, S. J. Werner, and D. S. Reinhold. 2002. Effect of roost harassment on cormorant movements and roosting in the Delta region of Mississippi. Waterbirds 25:44-51.

Tucker, C. S., J. L. Avery, and D. Heikes. 2004. Culture methods. Pages 166-195 in C. S. Tucker and J. A. Hargreaves, editors. Biology and culture of channel catfish. Elsevier B.V., Amsterdam, The Netherlands.

U.S. Department of Agriculture [USDA]. 2003a. Part I: reference of fingerling catfish health and production practices in the United States. U.S. Department of Agriculture, Animal and Plant Health Inspection Service, Veterinary Services, Centers for Epidemiology and Animal Health, National Animal Health Monitoring System (N406.1103), Fort Collins, Colorado, USA.

U.S. Department of Agriculture [USDA]. 2003b. Part II: reference of foodsize catfish health and production practices in the United States. U.S. Department of Agriculture, Animal and Plant Health Inspection Service, Veterinary Services, Centers for Epidemiology and Animal Health National Animal Health Monitoring System (N407.1103), Fort Collins, Colorado, USA.

Werner, S. J., and B. S. Dorr. 2006. Influence of fish stocking density on the foraging behavior of double-crested cormorants Phalacrocorax auritus. Journal of the World Aquaculture Society 37:121-125.

Wywialowski, A. P. 1999. Wildlife-caused losses for producers of channel catfish (Ictalurus punctatus) in 1996. Journal of the World Aquaculture Society 30:461-472.

Associate Editor: Breck. 